\title{
Coral reef research in Sesoko Island -50 years anniversary of Sesoko Station, University of the Ryukyus-
}

\author{
Saki Harii ${ }^{1}$, Masaya Morita ${ }^{1}$, Kazuhiko Sakai ${ }^{1}$, Frederic Sinniger $^{1}$, Akihiro Takemura $^{2}$, and \\ Hideyuki Yamashiro
}

\begin{abstract}
${ }^{1}$ Sesoko Station, Tropical Biosphere Research Center, Universtiy of the Ryukyus, 3422 Sesoko, Motobu, Okinawa 905-0227, Japan ${ }^{2}$ Faculty of Science, University of the Ryukyus, 1 Senbaru, Nishihara, Okinawa 903-0213, Japan
\end{abstract}

Published online: 31 January 2022

Sesoko Station was established as a marine laboratory of the Faculty of Science and Engineering, University of the Ryukyus in 1971 in Sesoko Island, northern Okinawa, Japan. Since then, our station has promoted and contributed coral reef research and education with domestic and international researchers. At first, land on

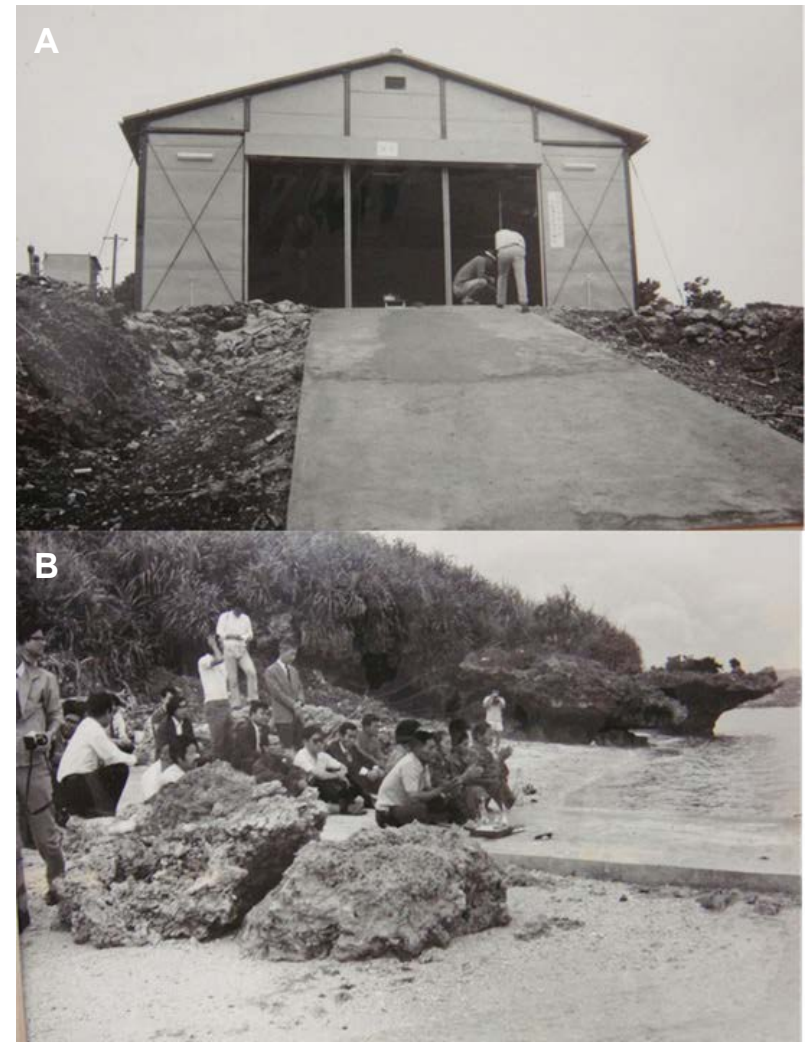

Fig. 1 A, First building (boatshed) of Sesoko Station in 1974. B, People pray for safety of field research. Photo: Shigeo Nakamura
Sesoko Island was kindly provided by Motobu Town in Okinawa and staff consisting of a head of the station (who held a position in the Faculty of Science), an associate professor and a technician were placed in the station. The boatshed was built in 1974 (Fig. 1), then the main research building was established in 1975, followed by the marine culturing building and outdoor aquaria in 1977 (Fig. 2 A).

During the first 10 years of its existence, the station aimed to provide seaside education and research facilities for biology students and professors of the faculty. With the increasing needs of research in ocean science, the station reorganized and was separated from the faculty. It became an independent facility of the University known as the Sesoko Marine Science Center in 1981 with several professors' positions. After this time, the center developed with the acquisition of a research boat (accommodating up to 20 people), and the renovation of the boatshed to serve a wide range of research fields including biology, fisheries, geology and physics/ chemistry. The center also developed internationally by inviting foreign researchers and the international symposium "Biodiversity and adaptive strategies of coral reef organisms" was held for the $20^{\text {th }}$ anniversary of the station in 1992 (Chair, Prof. Kiyoshi Yamazato). During this development, the predecessor of this journal, "Galaxea" was first issued as an international publication of Sesoko Marine Science Center in 1982 and research activities from Sesoko were widely reported (Fig. 3). The journal was terminated in 1997, but later the Japanese 

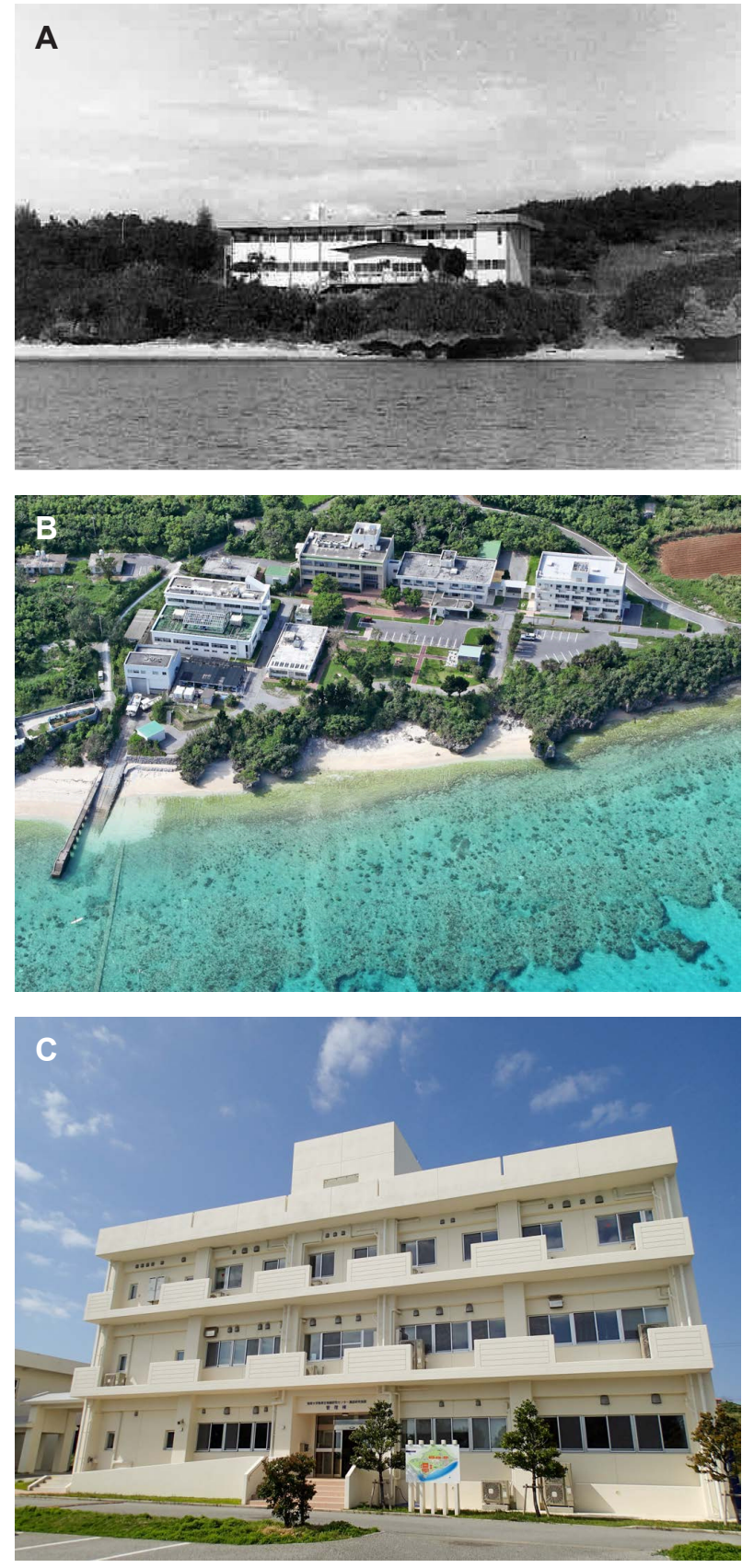

Fig. 2A-C A, Main buliding of the station with accommodation built in 1975. At the same time, the jetty was built. B, Overview of Sesoko Station (present). From the most right side the buildings are: the main building (see Fig. 2C), Research building, and the Collaboration building. The building-complex on the left includes the boatshed (with two boats), the shaded outside tank area and the Experimental Aquarium buildings. On the right side of this complex, the oldest remaining building of the station accomodates wet labs and aquarium space. $\mathrm{C}$, The main building was relocated and re-built as a three- floors building in 2014. Photo: C, Shohei Kadena

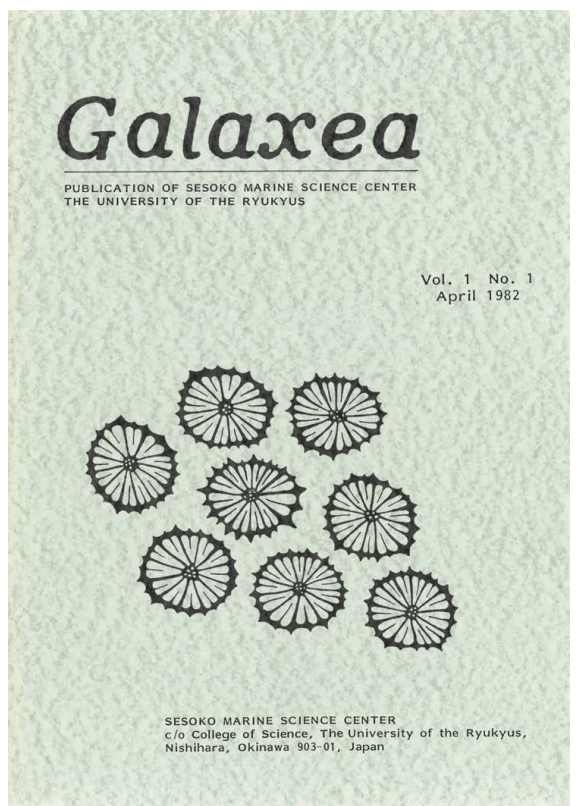

Fig. 3 Cover of the journal, Galaxea. It was published as the station's report twice per year.

Coral Reef Society took over the name as their international publication, "Galaxea, Journal of Coral Reef Studies" when the society was established.

In 1994, the Sesoko Marine Science Center was combined with Iriomote Station of Faculty of Agriculture and Nishihara Laboratory of Nishihara campus and became known as the Tropical Biosphere Research Center (TBRC). Research facilities at Sesoko were further developed with the Experimental Aquarium and Collaboration buildings in 2001 and 2003 (Fig. 2B). With large aquaria, the station accommodates large reef fish research (reviewed in Nakamura et al. 2022 in this issue). More recently, it was further merged with the Center of Molecular Bioscience in 2009 to expand the TBRC. It is authorized as a Joint Usage/Research Center by the Minister of Education, Culture, Sports, Science and Technology of Japan since 2010 for enhancing collaborative tropical science in Japan.

In the last decade, the original main building was destroyed and re-established in July 2014 with a student class and seminar rooms, and accommodations (Fig. 2C). The most recent significant development consisted in the upgrade of the engine of the boat Euphyllia III, significantly increasing the radius of the boat operations towards Ie Island, Minna Island and Nago Bay. Now the 
station accepts over 5,000 cumulative number of users per year both from domestic and aboard, supporting and enhancing collaborations on coral reef research in Japan.

Located in the middle of the Ryukyu Islands, close to well-developed fringing coral reefs (as visible in Takeuchi and Yamashiro 2022) and diverse mesophotic coral habitats (Sinniger et al. 2022), the station is ideally suited for coral reef research. The rich coral community that could be observed in front of the station in the 1980's (Fig. 4A, B) was damaged by bleaching events, with the main event occurring in 1998 triggering a change in coral composition, with some coral species completely disappearing from this shallow reef (Loya et al. 2001; van Woesik et al. 2011). However, while the reef in front of the station recovered progressively, high coral cover reefs can be observed at several sites around Sesoko Island. The biodiversity of the reefs near the station remains largely understudied, especially for groups other than
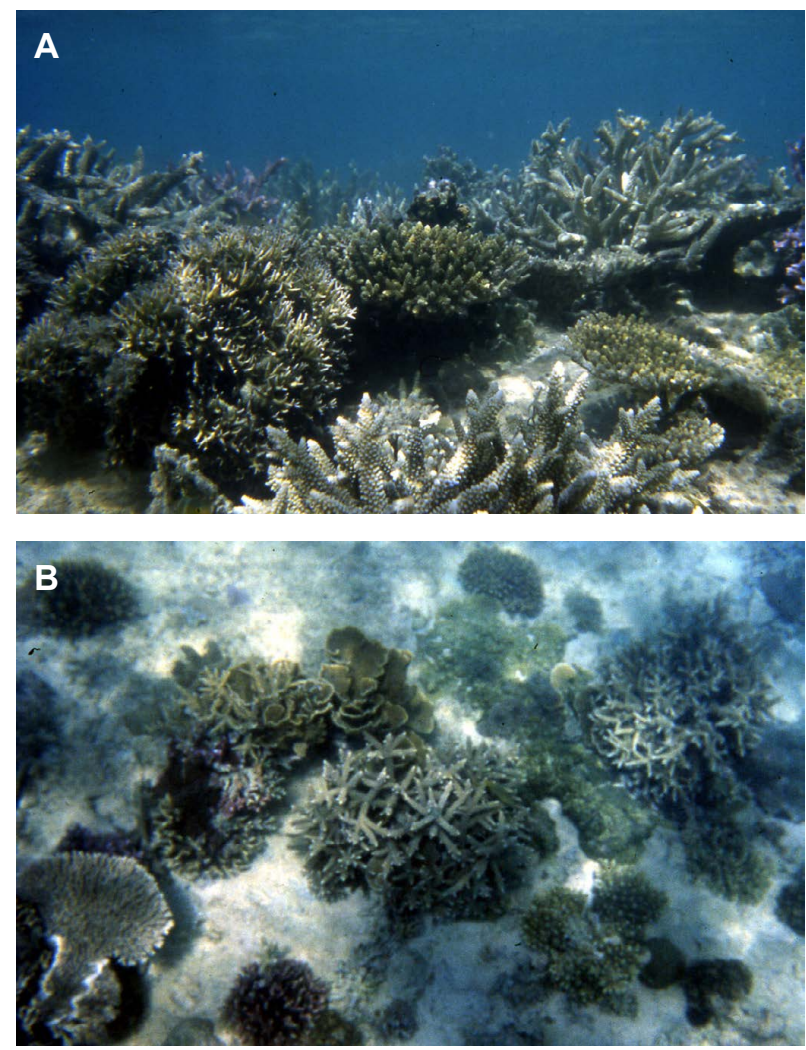

Fig. 4A, B Reefs in front of the station in 1980. A looser coral species from the bleaching (Loya et al. 2001), Seriatopora hystrix (left side in A) were commonly distributed with Acropora and Montipora. Photo: Kazuhiko Sakai corals or fishes. For example, in the last years the reefs around the station yielded several new species of gallforming crustaceans and nematodes (Kim and Yamashiro 2007; Leduc and Sinniger 2018; Leduc 2022; Yamashiro 2022).

The running sea water system available both in indoor labs and open-air tanks allowed for extensive research on the biology and ecology of coral reefs, including research on climate change and acidification (e.g.,Takahashi and Kurihara et al. 2013; Bell et al. 2022a, b). The ease to maintain corals in constant natural sea water flow and open-air tanks, combined to the diversity of corals accessible on the reefs nearby, made Sesoko Station an attractive facility to study corals reproductive biology (Heyward et al. 1987; Loya and Sakai 2008; Baird et al. 2022) and variable aspects of early life stages of corals (e.g., Harii et al. 2009; Figueiredo et al. 2014; Morita et al. 2019). Historically, the station has also been active in fish research, with behavioral work and some long-term work on reproductive biology of several tropical species (e.g. Udagawa et al. 2020 ; Kuwamura 2022; Murata et al. 2022; Nakamura et al. 2022). Beside coral and fish research, domestic and foreign visitors of the station conducted research on various topics such as plankton (e.g. Yuasa et al. 2022) or foraminifers (Hohenegger 2022).

Overall, in the last 50 years, Sesoko Station has provided researchers with outstanding possibilities to conduct field and laboratory research on the subtropical marine ecosystems around Sesoko Island and we expect that it will keep providing such service in the future.

\section{References}

Baird AH, Edwards AJ, Guest JR, Harii S, Hatta M, Lachs L, Mera H, Sinniger F, Abrego D, Ben-Zvi O, Bronstein O, Cabaitan PC, Cumbo VR, Eyal G, Eyal-Shaham L, Feldman B, Figueiredo J, Flot JF, Grinblat M, Heyward A, Hidaka M, Hirose M, Iguchi A, Isomura N, Kinzie RA, Kitanobo S, Kuba A, Levy O, Loya Y, Mezaki T, Mohamed AR, Morita M, Nojima S, Nozawa Y, Prasetia R, Puill-Stephan E, Ramirez-Portilla C, Rapuano H, Rosenberg Y, Sakai Y, Sakai K, Shlesinger T, Terraneo TI, Yakovleva I, Yamamoto HH, Yamazato K (2022) A coral spawning calendar for Sesoko Station, Okinawa, Japan. Galaxea, J Coral Reef Stud 24: 41-49

Bell T, Manullang C, Kumagai NH, Sakai K, Suzuki A, Iguchi 
A (2022a) Calcification responses of subtropical corals to ocean acidification: a case study from Sesoko Island, Okinawa, Japan. Galaxea, J Coral Reef Stud 24: 51-61

Bell T, Manullang C, Sakai K, Suzuki A, Iguchi A (2022b) Near-future levels of $p \mathrm{CO}_{2}$ impact skeletal weights of coral primary polyps (Acropora digitifera). Galaxea, J Coral Reef Stud 24: 63-68

Figueiredo J, Baird AH, Harii S, Connolly SR (2014) Increased local retention of reef coral larvae as a result of ocean warming. Nat Clim Change 4: 498-502. doi:10.1038/ nclimate 2210

Harii S, Yasuda N, Rodriguez-Lanetty M, Irie T, Hidaka M (2009) Onset of symbiosis and distribution patterns of symbiotic dinoflagellates in the larvae of scleractinian corals. Mar Biol 156: 1203-1212

Heyward A, Yamazato K, Yeemin T, Minei M (1987) Sexual reproduction of corals in Okinawa. Galaxea 6: 331-343

Hohenegger J, Kinoshita S, Briguglio A, Eder W, Wöger JA (2022) Growth of the foraminifer Nummulites venosus in nature and culture. Galaxea, J Coral Reef Stud 24: 77-89

Kim I-H, Yamashiro H (2007) Two species of cyclopoid copepods (Crustacea) inhabiting galls on scleractinian corals in Okinawa, Japan. J Crustac Biol 27: 319-326

Kuwamura T (2022) Behavioral ecology of coral reef fishes studied at Sesoko Station since 1982. Galaxea, J Coral Reef Stud 24: 19-30

Loya Y, Sakai K (2008) Bidirectional sex change in mushroom stony corals. Proc R Soc B 275: 2335-2343

Loya Y, Sakai K, Yamazato K, Nakano Y, Sambali H, van Woesik R (2001) Coral bleaching: the winners and the losers. Ecol Lett 4: 122-131

Leduc D, Sinniger F (2018) Combining morphological and molecular data to classify Laxus sakihariiae sp. n., a new stilbonematine nematode (Nematoda: Desmodoridae) from the coast of Sesoko Island, Japan. Nematology 20: 81-95

Leduc D (2022) Zalonema sesokoensis n. sp. (Nematoda: Desmodoridae), a new nematode species from subtidal sediments of Sesoko Island, Japan. Galaxea, J Coral Reef Stud 24: 91-97

Morita M, Kitanobo S, Nozu R, Iwao K, Fukami H, Isomura N (2019) Reproductive strategies in the intercrossing corals Acropora donei and A. tenuis to prevent hybridization
Coral Reefs 38: 1211-1223

Murata R, Amagai T, Izumida D, Mushirobira Y, Nozu R, Soyano K (2022) Lunar-related maturation and spawning migration in the honeycomb grouper, Epinephelus merra. Galaxea, J Coral Reef Stud 24: 31-38

Nakamura M, Nozu R, Nakamura S, Higa M, Bhandari RK, Kobayashi Y, Horiguchi R, Komatsu T, Kojima Y, Murata R, Soyano K, Ogawa S, Hirai T, Matsubara H, Tokumoto T, Kobayashi T, Kagawa H, Adachi S, Yamauchi K, Nagahama Y (2022) Morphological and physiological studies on sex change in tropical fish: Sexual plasticity of the ovaries of hermaphroditic and gonochoristic fish. Galaxea, J Coral Reef Stud 24: 5-17

Sinniger F, Albelda RL, Prasetia R, Rouzé H, Sitorus ED, Harii S (2022) Overview of the mesophotic coral ecosystems around Sesoko Island, Okinawa, Japan. Galaxea, J Coral Reef Stud 24: 69-76

Takahashi A, Kurihara H (2013) Ocean acidification does not affect the physiology of the tropical coral Acropora difitifera during a 5-week experiment. Coral Reefs 32: 305-314

Takeuchi I, Yamashiro H (2022) Bird-view of the reef flat off Sesoko Station on the east coast of Sesoko Island, Okinawa, Japan obtained by aerial survey. Galaxea, J Coral Reef Stud 24: 119-120

Udagawa S, Hur SP, Byun JH, Takekata H, Takeuchi Y, Takemura A (2020) Verification of differentially expressed genes in relation to hydrostatic pressure in the brain of two wrasse species with high-tide preference in spawning. J Fish Biol 97: 1027-1038

van Woesik, Sakai K, Ganase A, Loya Y (2011) Revisiting the winners and the losers a decade after coral bleaching. Mar Ecol Prog Ser 434: 67-76

Yamashiro H (2022) Geographic distribution of a gall-inducing copepod Allopodion ryukyuensis on Montipora corals along Ryukyu Archipelago, Japan, and Green Island, Taiwan. Galaxea, J Coral Reef Stud 24: 99-103

Yuasa T, Horiguchi T, Takahashi O (2022) Ultrastructural observation of a symbiotic dinoflagellate Zooxanthella nutricula from radiolarians collected off the northwestern coast of Okinawa Island, Japan. Galaxea, J Coral Reef Stud 24: 105-117

(C) Japanese Coral Reef Society 